\title{
STUDI TENTANG PENGETAHUAN INDEGENEOUS LANSIA DALAM MENGOBATI DAN MENJAGA KESEHATAN ANAK
}

\author{
Oleh: \\ Sri Iswanti, Kartika Nur Fathiyah, dan Eko Budi Prasetyo \\ Staf Pengajar FIP UNY
}

\begin{abstract}
Tujuan penelitian ini adalah mengidentifikasi pengetahuan indegeneous yang dimiliki lansia dalam mengobati dan menjaga kesehatan anak, serta mengkajinya secara ilmiah bersama dengan pakar pengobatan tradisional dari lingkungan akademik.

Penelitian ini menggunakan pendekatan deskriptif kualitatif. Dilakukan di Daerah Istimewa Yogyakarta dengan mengambil setting di daerah perkotaan dan pedesaan. Informan penelitian secara keseluruhan berjumlah 32 orang. Data penelitian diperoleh melalui metode dokumentasi, wawancara mendalam, dan observasi. Hasil penelitian melalui ketiga metode tersebut kemudian diverifikasi kepada pakar pengobatan tradisional khususnya jamu.

Hasil penelitian menunjukkan bahwa untuk kasus-kasus penyakit ringan lansia mengobati anak cucunya dengan jamu, namun bila penyakitnya berat dibawa ke dokter. Bahan yang digunakan untuk mengolah jamu memanfaatkan bahan yang ada di sekitar dengan berbagai bentuk pengolahan. Kajian ilmiah pakar jamu terhadap resep-resep jamu yang diberikan oleh lansia direkomendasi sebagai berikut: a) disarankan digunakan karena kandungannya telah terbukti secara ilmiah b) diragukan, karena bahan yang dikandung tidak ada kaitannya dengan penyakit yang diderita anak, atau secara ilmiah tidak masuk akal, dan c) dilarang, karena kandungan bahan dan pengolahannya justru berbahaya untuk kesehatan. Lansia berusaha menularkan pengetahuan tentang jamu kepada anak-cucu, tetapi tidak semua resep diikuti karena anak kurang telaten dan lebih percaya dokter, tidak praktis, lama, dan takut berakibat fatal. Selain itu, bahan tradisional sulit dicari dan dosis tidak diketahui pasti ukurannya.
\end{abstract}

Kata Kunci: Pengetahuan Indegeneous Lansia, Pengobatan Anak 


\section{PENDAHULUAN}

Berbagai upaya akan dilakukan orang tua untuk memenuhi tugas dan kewajibannya terhadap anak sebagai titipan Tuhan. Dalam hubungannya dengan kesehatan, orang tua selalu berusaha agar anaknya hidup dengan sehat sehingga dapat tumbuh dan berkembang optimal.

Usaha orangtua agar anak tetap sehat sudah dilakukan orang tua sejak jaman dahulu. Usaha-usaha yang dilakukan pada masa lalu merupakan penerapan dari pengetahuan indigenous (indigenous knowledge). Yaitu pengetahuan tradisional atau pengetahuan lokal dan spesifik yang ada di dalam masyarakat setempat dan didapatkan secara turun temurun.

Dalam memelihara kesehatan, nenek moyang memiliki cara yang sangat beragam, mulai dari pemijatan, pemberian berbagai ramuan untuk untuk diminum, dioleskan, untuk pemakaian luar dalam bentuk pilis, tapel, bobok atau boreh, dimintakan do'a kepada orang pintar, sampai dengan tindakan-tindakan yang kadang-kadang kurang dapat diterima akal sehat.

Meskipun kebiasaan menggunakan jamu atau obat tradisional sudah begitu membudaya pada masyarakat Indonesia, namun kadang-kadang masyarakat tidak mengetahui kandungan unsurunsur serta khasiat yang ada dalam bahan-bahan jamu yang digunakan. Hal ini disebabkan karena penggunaan jamu dilakukan secara turun-temurun.

Pemakaian jamu dan obat tradisional lainnya yang dilakukan secara turun-temurun tidak terlepas dari peran para lanjut usia dalam melestarikan budaya. Penelitian yang dilakukan oleh Siti Partini (1999) mengenai perilaku berobat pada lansia, antara lain menyimpulkan bahwa salah satu cara menjaga kesehatan yang dilakukan masyarakat Daerah Istimewa Yogyakarta (terutama wanita) adalah dengan sering mengkonsumsi ramuan jamu Jawa yang harganya relatif murah. Hasil penelitian Iswanti (2001) mengenai pola hidup lansia di Daerah Istimewa Yogyakarta 
menemukan bahwa para lanjut usia di DIY menjaga kesehatan tubuhnya dengan minum jamu dan berolah raga, sedangkan untuk kesehatan mental/psikologis dengan hidup sumeleh (menyerahkan diri kepada Tuhan Yang Maha Esa).

Hasil-hasil penelitian tersebut lebih menekankan penggunaan jamu Jawa pada masyarakat umum, lansia, dan wanita. Sebetulnya, jamu dapat digunakan juga untuk anak-anak. Menurut Geertz (1961) obat tradisional bukan semata-mata hanya untuk wanita namun tersedia pula untuk laki-laki dan anak-anak.

Jamu memiliki beberapa keunggulan, seperti toksisitasnya rendah dan efek samping yang ditimbulkan ringan. Namun demikian jamu juga memiliki beberapa kelemahan diantaranya: khasiatnya belum diuji secara khusus; takarannya diragukan ketepatannya; serta daya sembuhnya lebih lambat daripada obat modern (Werner dkk, 1995). Untuk mengatasi kelemahan-kelemahan tersebut, perlu dilakukan berbagai langkah antara lain dengan mengkaji secara ilmiah khasiat tiap bahan yang digunakan, takaran, proses penyiapan, sampai dengan cara menggunakan dan menyimpannya, sehingga jamu dapat disejajarkan dengan obat-obatan modern. Kajian tersebut dapat dilakukan melalui serangkaian penelitian.

Penelitian ini dimaksudkan untuk mengidentifikasi sejauh mana pengetahuan indigenous yang dimiliki oleh para lansia dalam mengobati dan menjaga kesehatan anak. Kemudian hasil identifikasi tersebut diverifikasikan kepada ahli dalam bidang obat-obatan tradisional dari kalangan akademisi, sehingga didapatkan pengetahuan yang lebih akurat dan dapat dipertanggungjawabkan secara ilmiah.

\section{Cara Penelitian}

Penelitian ini menggunakan pendekatan kualitatif dalam bentuk deskriptif kualitatif. Penelitian dilakukan di DIY dengan mengambil setting di daerah perkotaan dan daerah pedesaan. Lokasi untuk daerah perkotaan di kampung Bugisan, Kalurahan Patangpuluhan, Kecamatan Wirobrajan Kota Yogyakarta. Untuk 
daerah pedesaan di Desa Ngestiharjo, Kecamatan Kasihan, Kabupaten Bantul, dan Desa Wedomartani, Kecamatan Ngemplak, Kabupaten Sleman.

Subjek penelitian adalah para lanjut usia yang memiliki perbendaharaan pengetahuan indigenous yang berhubungan dengan kesehatan, serta melakukan pengobatan tersebut kepada anak/cucunya. Adapun teknik penentuan informan dilakukan dengan purposive sampling.

Informan penelitian secara keseluruhan berjumlah 32 orang. Data penelitian diperoleh melalui metode dokumentasi, wawancara mendalam dan observasi. Hasil penelitian melalui ketiga metode tersebut kemudian diverifikasi kepada pakar pengobatan tradisional khususnya jamu. Dalam hal ini pakar yang dipilih adalah Prof Dr Mae Sri Hartati yang merupakan guru besar kedokteran serta ahli obat-obatan tradisional di Fakultas Kedokteran Universitas Gadjah Mada.

Data yang diperoleh dianalisis dengan analisis kualitatif dilanjutkan dengan analisis tematik.

\section{PEMBAHASAN}

Rentang usia informan dari Kampung Bugisan kota Yogyakarta berkisar antara 54 tahun sampai 59 tahun. Padahal menurut Undang-Undang kesejahteraan lanjut usia batas paling rendah untuk disebut sebagai lansia adalah 60 tahun,. Ketika hal itu ditanyakan pada pengurus kelompok lansia dan beberapa anggota, sepengetahuan mereka batas bawah usia lansia adalah 50 tahun. Pada usia 50 tahunan responden merasa sudah tua, dan merasa perlu bergabung dengan kelompok lansia. Data ini bermakna positif karena aktivitas kelompok lansia memiliki intensitas yang cukup tinggi dan cukup diminati. Selain itu, bergabungnya kelompok usia pralansia dengan kelompok lansia ini akan semakin meningkatkan kesiapan fisik maupun psikologis calon lansia sebelum benar-benar memasuki usia lansia yaitu 60 tahun ke atas. Akan tetapi sisi negatifnya, data tersebut menunjukkan belum 
tersosialisasinya secara benar kriteria kelompok lansia di kalangan masyarakat.

Informan dari kabupaten Bantul sebagian besar berpendidikan sarjana dan pekerjaannya adalah guru atau dosen. Rentang usia berkisar antara 54 tahun sampai 76 tahun. Meskipun informan penelitian sebagian besar berpendidikan tinggi yang diasumsikan cenderung lebih memilih pengobatan modern untuk mengatasi penyakit anak, temuan di lapangan menunjukkan bahwa informan justru memiliki pengetahuan tinggi tentang pengobatan tradisional dan memilihnya untuk pengobatan penyakit ringan pada anak. Selain itu, informan juga cenderung menularkan pengetahuan indegeneous tersebut pada anak-anaknya.

Dilihat dari pekerjaannya, informan di Kabupaten Sleman bekerja sebagai PNS dan lainnya sebagai ibu rumah tangga. Rentang usia berkisar antara 60 tahun sampai 84 tahun. Ada kecenderungan tingginya penggunaan jamu khususnya untuk penyakit ringan karena didukung kemudahan mendapatkan bahan jamu di lingkungan sekitar.

Dari buku-buku yang ditemukan mengenai obat-obatan tradisional antara lain yang disusun oleh Adhiwibowo (2009), dicantumkan resep-resep pengobatan tradisional anak. Adapun penyakit yang tercantum buku tersebut dan diatasi dengan obat tradisional antara lain demam dengan jeruk nipis, bawang merah, dan kayu putih; mempercepat anak berjalan dengan kencur, beras, dan kemangi. Meskipun buku tersebut disusun oleh apoteker, akan tetapi uraian ilmiah tentang kandungan bahan belum ada. Buku lain, dikarang Baskara (2010) yang berjudul Sehat Alami Khasiat Buah yang secara rinci menjelaskan bahan beserta kandungannya secara ilmiah.

Temuan di lapangan menunjukkan bahwa sebagian besar responden memanfaatkan obat tradisional untuk mengobati penyakit ringan yang diderita anak. Sedangkan untuk mengobati penyakit berat, seluruh informan penelitian mempercayakan pengobatan modern oleh dokter. Penyakit yang dipandang ringan antara lain 
batuk. Batuk diatasi menggunakan campuran jeruk nipis dengan kecap. Ada juga informan yang memodifikasi resep batuk ini dengan memanggang jeruk nipis, diberi kapur sirih dan minyak kelapa yang selanjutnya diminumkan pada anak.

Penyakit ringan yang diatasi dengan resep tradisional adalah panas. Panas diatasi dengan membaluri tubuh anak dengan parutan bawang merah dicampur dengan minyak kayu putih. Selain itu, tubuh anak yang panas juga diatasi dengan mengkompres anak dengan air panas dan diberi minyak telon. Mengkompres dahi anak yang panas dengan jeruk nipis ditambah minyak kayu putih juga dilakukan salah satu responden untuk mengatasi anak yang panas. Salah seorang responden menggunakan daun dadap serep untuk mengkompres dahi anak yang panas.

Biasanya panas juga diikuti dengan pilek. Menurut responden pilek dapat diatasi dengan biji pala dicampur bawang merah, dipupukkan di kepala. Tujuannya adalah mengatasi hidung mampet. Selain itu, pilek pada anak dapat dikurangi dengan menjemur anak pada pagi hari.

Data lain yang ditemukan adalah bila terserang penyakit mencret atau diare pada anak, responden mengatasinya dengan memanfaatkan tanaman dan buah yang sepet-sepet dengan digerus atau ditumbuk, diperas, dan air perasannya diminumkan pada anak. Diare ini juga diatasi dengan meminumkan air teh pahit pada anak. Salah seorang responden juga menjelaskan bahwa perasan kunir asem dan temu lawak yang ditumbuk juga dapat digunakan untuk mengatasi diare pada anak. Selain dengan cara diminumkan, diare dapat diatasi dengan menempelkan (menapelkan) kunir dan injet di perut.

Untuk menambahkan nafsu makan anak, beberapa responden mencoba meminumi anak perasan kunyit parut ditambah madu. Bawang merah dan puyang mentah matang masing-masing seruas ibu jari ditambah garam yang diminumkan pada anak juga dapat meningkatkan nafsu makan anak. Resep lain untuk mengatasi kesulitan makan anak adalah tempe busuk kukus ditambah temu 
ireng. Air perasan daun papaya tumbuk juga dapat meningkatkan nafsu makan anak.

Penyakit demam berdarah, menurut sebagian responden diatasi dengan jambu biji. Sedang penyakit cacingan pada anak, menurut responden diatasi dengan cekok ndak-ndak cacing, atau buah kecubung dimakan dengan pisang, atau dapat juga diobati dengan buah kecubung dikukus dengan daun kecubung dan selanjutnya dimakan oleh penderita.

Beberapa bahan lain untuk mengobati anak antara lain cacing untuk tipus, kuning telur dan madu untuk penyakit gabagen, perasan parutan wortel untuk penyakit cacing kremi, irisan emponempon yang direbus, dan kemudian digunakan untuk mandi untuk mengobati gatal-gatal dan sakit kulit. Kembang leson dapat mengobati lesu sesudah sakit. Caranya anak dimandikan dengan menggunakan ramuan kembang leson yang terdiri dari berbagai empon-empon, bunga mawar, kenanga, melati, daun pandan, dan serutan kayu secang, kemudian direbus dan ditambahkan sedikit garam dapur. Ramuan ini direbus, hangat-hangat digunakan untuk memandikan anak. Untuk menghilangkan bau amis pada ASI digunakan ramuan kunir, ketumbar, asem kawak yg harus dikunyah oleh ibu, air dari ramuan ini ditelan oleh ibu, sedangkan ampasnya dibalurkan disekitar payudara. Jamu uyup-uyup yang dibuat dari daun-daunan dan empon-empon seperti kunyit, asem, yang kemudian ditumbuk dan diperas, juga dapat berkhasiat menyegarkan ASI. Untuk melancarkan ASI dapat digunakan sayur daun katuk.

Ramuan dadap ri, adas pulo waras, dan dlingo bengle untuk memulihkan kondisi tubuh setelah cangkrangen. Telur ayam, babal madu kucing (babal yang baru jatuh), daun so ditumbuk semua dicampur dan dibalurkan ke tubuh yang terkena gabag untuk mengobati gabagen. Air tajin dengan irus batok ditambah garam diminumkan hangat-hangat untuk mengobati pancingen. Daun sembukan untuk mengatasi masuk angin, dan beras kencur untuk memulihkan tulang yang kecetit atau lebam (menyonyo). Untuk luka baru dapat diobati dengan daun regedeg (daun kemlandingan) 
yang diremas-remas kemudian ditempelkan di luka yang baru. Luka baru tersebut juga dapat diobati dengan getah daun yodium atau lugut yang diambil dari daun kelapa yang dikerok, kemudian ditempelkan di luka baru. Dapat juga dari getah daun patikan yang dioleskan di luka baru tersebut.

Untuk menjarangkan kelahiran dianjurkan memakan ketimun dalam jumlah banyak dan menghindari makan kecambah (thokolan).Untuk menyehatkan bayi dalam kandungan lansia menyarankan agar ibu hamil minum jamu wejah yang dibuat dari kunir, kencur, dan empon-empon yang lain yang ditumbuk kemudian diperas dan diminum.

Temuan dari responden di kalangan lansia selanjutnya dikonsultasikan pakar. Berdasarkan masukan pakar dalam hal ini adalah guru besar kedokteran UGM yaitu Prof Dr Mae Sri Hartati dapat diperoleh informasi sebagai berikut.

Pengobatan tradisional yang selama ini diterapkan lansia untuk mengobati penyakit anak, menurut pakar pengobatan ada beberapa bahan dan pengolahan yang tepat namun ada juga yang justru berbahaya untuk kesehatan. Beberapa resep dan bahan yang sudah dipandang tepat oleh pakar antara lain kunir untuk mengobati diare. Alasannya kunir bersifat anti bakteri sehingga dapat digunakan untuk membasmi bakteri penyebab mencret. Dari sisi pengolahan, menurut pakar, pengolahan kunir oleh responden dengan cara ditapelkan di perut bersama kapur sirih untuk mengatasi mencret kurang tepat karena manfaatnya kurang optimal. Sebaiknya kunir tidak perlu ditambah kapur sirih dan pengolahannya cukup dengan diparut saja dan diambil airnya dengan terlebih dahulu mencuci bersih bahan sebelum diolah. Selain itu, untuk pengolahan kunyit dengan cara diiris, diangin-anginkan dan ditambah irisan temu lawak untuk mencegah diare dan selanjutnya direbus dapat diterima namun perebusan tidak lebih 10 menit agar kandungan aktifnya tidak rusak.

Tindakan responden mengatasi diare dengan memanfaatkan teh kental menurut pakar dapat diterima karena teh mengandung 
kafein 2-3 \% dan juga serat $27 \%$. Pemanfaatan air kacang hijau untuk mengatasi diare juga dapat dilakukan karena air kacang hijau mengandung nutrisi penting untuk daya tahan tubuh. Akan tetapi pemanfaatan air kacang hijau ini tidak perlu dengan menghentikan penggunaan asi seperti yang dilakukan salah satu responden yaitu yaitu Ibu $\mathrm{Su}(57 \mathrm{th})$ karena asi merupakan asupan gizi yang paling baik untuk anak, terutama untuk anak yang sakit.

Bahan tradisional lain yang menurut pakar memiliki bukti ilmiah untuk dapat digunakan dalam pengobatan anak antara lain bawang merah atau biji pala untuk mengobati pilek, masuk angin, atau panas. Bahan-bahan ini banyak mengandung minyak atsiri yang dapat menghangatkan badan, melegakan pernafasan dan mencegah hidung tersumbat. Selain itu, pemanfaatan jeruk nipis dan kencur untuk untuk mengatasi batuk dipandang pakar sangat tepat karena jeruk nipis mengandung limonene, filadrin, asam sitrat, dan vitamin serta mineral, sedangkan kencur mengandung minyak atsiri seperti sineol, asam metal kanil, asam sinamik, alkaloid, yang sebagian senyawa itu dapat berperan untuk mengencerkan dahak. Bahan-bahan ini, menurut pakar jika dikombinasikan dengan inggu seperti yang sudah dianut oleh para responden lansia semakin berkhasiat karena inggu mengandung minyak atsirimetil nonalketane sampai $90 \%$ sehingga dapat membantu kerja jeruk nipis.

Penggunaan sirih untuk mengatasi batuk dan mimisan dipandang pakar juga sangat tepat karena sirih mengandung zat yang berkhasiat sebagai antiseptik sehingga dapat membunuh kuman penyebab infeksi.

Pemanfaatan tempe busuk dan rimpang temu-temuan untuk menambah nafsu makan pada anak menurut pakar juga dipandang tepat karena tempe busuk dan rimpang temu-temuan ini mengandung banyak vitamin B12 yang dapat merangsang nafsu makan pada anak.

Penggunaan buah jambu biji oleh responden untuk mengatasi demam berdarah dan mencegah diare juga sangat 
disetujui pakar karena jambu biji banyak mengandung vitamin $\mathrm{C}$, $\mathrm{B}$, kalsium, fosfor, besi, dan pectin dan mineral.

Pemanfaatan beras kencur untuk kesleo atau bengkak juga disetujui pakar karena kencur mengandung minyak atsiri yang dapat berperan sebagai anti inflamasi (anti radang), sedang beras untuk media pembawa kencur.

Pemanfaatan daun ungu untuk mengatasi tidak bisa buang air besar atau ambeien juga dipandang tepat oleh pakar karena daun ungu mengandung anti imflamasi dan laxantia, demikian juga pemanfaatan rebusan daun salam untuk mengatasi kaki pegal dipandang pakar cukup tepat karena mengandung eugenol sebagai anti inflamasi.

Pengunaan daun kumis kucing untuk mengatasi anyanganyangen menurut pakar juga dipandang cukup bermanfaat karena kumis kucing mengandung zat peluruh (diuretic)yang dapat membantu melancarkan air seni. Selain itu, penggunaan daun tempuyung untuk mengatasi asam urat dapat diterima secara ilmiah karena mengandung flovanoid yang dapat membasmi asam urat. Namun penggunaannya untuk kolesterol, pakar menyatakan belum ada bukti ilmiahnya.

Selain masukan-masukan tersebut pakar juga menyetujui penggunaan bahan untuk pengobatan anak pada lansia namun belum menjelaskan secara detail kandungannya. Misalnya penggunaan daun dadap serep untuk mengatasi penyakit panas, penggunaan cacing untuk penyakit tipus (namun menurut pakar perlu dicermati proses pengeringannya yang harus higienis), kembang leson untuk keadaan lesu sesudah sakit, tapel dada dari bahan asem, ketumbar, kunir, uyup-uyup untuk melancarkan asi.

Selain uraian di atas, pakar juga masih meragukan pemanfaatan bahan-bahan tertentu untuk mengatasi penyakit anak. Misalnya pengompresan air panas dengan minyak telon, penggunaan kunyit untuk meningkatkan nafsu makan, pemanfaatan bunga tempoyang untuk mengatasi batuk, pemanfaatan telur ayam ditambah babal madu kucing yang dibalurkan tubuh penderita 
untuk mengatasi gabagen, penggunaan minyak goreng dengan cara dioleskan di dahi untuk mengatasi pilek, daun sembukan untuk masuk angin, tembakau kedu dan minyak goreng yang ditapelkan di pusar penderita untuk mengatasi masuk angin, jahe dan asam kawak untuk mengobati luka, kencur untuk belekan, getah jipang untuk kaki merekah. Alasannya reep-resep tersebut belum teruji secara klinis sehingga diragukan kemanfaatannya.

Namun demikian, ada beberapa penggunaan bahan dan pengolahannya yang dipandang tidak ada manfaatnya atau bahkan justru berbahaya oleh pakar. Misalnya penggunaan babal untuk mengatasi diare. Menurut pakar, babal justru mengandung albuminaria dan karbohidrat yang sama sekali tidak memiliki sumbangan apapun untuk mengatasi penyakit diare. Selain itu, pemanfaatan bengle ditambah bawang merah untuk mengatasi diare seperti yang dilakukan Ibu Jat (60 tahun) dipandang pakar justru berbahaya karena bengle banyak mengandung pencahar sehingga justru tidak boleh untuk obat mencret karena memperparah penyakit diare. Bengle, menurut pakar justru lebih tepat untuk obat sembelit.

Bahan lain yang menurut pakar berbahaya namun digunakan responden adalah buah kecubung. Buah kecubung yang dimanfaatkan Ibu Nga (58 th) dan Rus (54 th) untuk mengobati penyakit cacingan pada anak justru sangat berbahaya karena zat racun yang dikandung yaitu biosfen, afropin, dan scopolamine. Sebaliknya penggunaan bahan wortel untuk mengobati cacing kremi diperbolehkan karena wortel justru mengandung vitamin dan mineral. Selain itu, pemanfaatan temu ireng atau mlanding asli untuk mengobati cacing juga diperbolehkan karena bahan tersebut dapat merangsang nafsu makan anak yang mengalami cacingan sehingga daya tahan tubuhnya meningkat.

Bahan lain yang juga berbahaya menurut pakar adalah penggunaan penggunaan pelepah daun kelapa yang masih ada bulunya (lugut) untuk mengobati luka seperti yang dilakukan responden Ibu G (75 th). Menurut pakar cara tersebut belum ada 
bukti ilmiahnya. Bahkan bulu pada pelepah tersebut dapat menyebabkan alergi pada luka. Adapun pengobatan luka khususnya luka bakar yang dapat diterima oleh pakar adalah pengobatan luka dengan menggunakan daun lidah buaya karena kandungan aloin aloesin yang dapat mendinginkan luka bakar. Selain itu, pengunaan lemak ayam untuk mengobati luka bakar juga dapat dilakukan karena lemak ayam bersifat dingin hampir seperti vaseline kuning yang sering digunakan pengobatan modern untuk mengatasi luka bakar. Penggunaan garam untuk mengatasi luka bakar juga diperbolehkan pakar karena garam mengandung elektrolit yang sangat berguna untuk tubuh. Meskipun penggunaan bawang merah atau kencur untuk mengatasi luka baru menurut pakar diperbolehkan, akan tetapi, disarankan tidak dilakukan pada anak karena menimbulkan efek pedih pada luka. Yang dipandang cukup tepat justru memanfaatkan luka baru dengan menggunakan getah daun yodium karena kandungan yodium di dalamnya yang berfungsi mengeringkan luka.

Temuan di lapangan menunjukkan bahwa responden mendapatkan jamu atau bahan jamu secara beragam. Sebagian responden, mendapatkan jamu dengan cara membeli seperti kunir asem, jamu paitan, atau uyup-uyup untuk menyegarkan asi. Selain itu, bahan jamu didapatkan di rumah sendiri karena sudah ada di rumah sebagai sediaan yang selalu ada. Bahan jamu yang tidak dimiliki respoden namun dimiliki tetangga oleh responden diperoleh dengan cara meminta tetangga. Data ini menunjukkan bahwa pengolahan jamu oleh lansia juga memupuk persaudaraan dan semakin meningkatkan interaksi lansia dengan anggota masyarakat lain.

Untuk pengolahan bahan-bahan tersebut, sebagian besar responden memanfaatkan peralatan modern untuk mengolah. Alasannya agar lebih cepat dan lebih praktis.

Pengetahuan lansia tentang jamu-jamuan ini diperoleh melalui banyak cara. Antara lain secara turun temurun, dari informasi teman, dari coba-coba yang kemudian menjadi pengalaman 
pribadi dan akhirnya juga disampaikan pada orang lain secara getok tular (bergantian), serta dari media massa.

Responden berusaha menularkan pengetahuan tersebut kepada anak-cucu. Akan tetapi kenyataan menunjukkan bahwa tetapi tidak semua resep tradisional diikuti anak. Menurut responden anak-anak atau cucu cenderung kurang telaten, keras kepala dan lebih percaya dokter. Selain itu, bahan tradisional sulit dicari dan dosis tidak diketahui pasti ukurannya sehingga anak ragu. Alasan lain yang yang diajukan anak cucu responden antara lain repot, kotor, tidak praktis, lama, dan takut kalau penyakit semakin berat dan justru berakibat fatal.

Yang diikuti oleh sebagian besar anak-cucu responden hanya resep masuk angin atau panas dengan cara membalurkan parutan bawang merah ditambah minyak kayu putih ke tubuh anak dan jus jambu biji untuk mengatasi demam berdarah, serta memandikan anak dengan kembang leson jika capek atau gabagen.

Pengalaman responden akan sulitnya menularkan pengetahuan indegeneous tentang mengobati anak ini menjadikan responden memandang perlu ditumbuhkannya kesadaran generasi muda secara terus menerus sehingga resep tradisional ini tetap lestari sebagai salah satu cara pengobatan pada anak.

\section{SIMPULAN}

Pengobatan yang dilakukan oleh lansia terhadap anak-cucunya untuk kasus-kasus penyakit ringan diobati dengan jamu, namun bila penyakitnya berat dibawa ke dokter.

Bahan yang digunakan untuk membuat jamu antara lain empon-empon atau rimpang, daun-daunan, bunga, buah, madu, telur, getah, bulu, umbi, kayu, minyak. Cara membuat jamu dengan cara direbus, ditumbuk, dikunyah, dimakan dalam kondisi segar, atau disayur. Cara menggunakan jamu: diminum, dimakan, dioleskan, dipopokkan. 
Kajian secara ilmiah oleh guru besar kedokteran di bidang jamu dari Universitas Gajah Mada tentang resep-resep jamu yang diberikan oleh lansia, direkomendasi sebagai berikut: a) disarankan digunakan karena kandungannya telah terbukti secara ilmiah b) diragukan, karena bahan yang dikandung tidak ada kaitannya dengan penyakit yang diderita anak, atau secara ilmiah tidak masuk akal, dan c) dilarang, karena kandungan bahan dan pengolahannya justru berbahaya untuk kesehatan penderita.

Responden berusaha menularkan pengetahuan tentang jamu kepada anak-cucu, tetapi tidak semua resep tradisional diikuti anak karena kurang telaten, keras kepala dan lebih percaya dokter. Selain itu, bahan tradisional sulit dicari dan dosis tidak diketahui pasti ukurannya sehingga anak ragu. Alasan lain yang yang diajukan anak cucu responden antara lain repot, kotor, tidak praktis, lama, dan takut kalau penyakit semakin berat dan justru berakibat fatal.

Saran-saran yang dapat diberikan atas dasar simpulan tersebut adalah:

1. Perlu dilakukan kajian secara ilmiah tentang resep-resep jamu yang diwariskan secara turun temurun.

2. Perlu dilakukan sosialisasi kepada masyarakat melalui berbagai forum pertemuan, baik untuk resep jamu yang benar maupun yang tidak boleh digunakan.

3. Perlu dilakukan pelatihan tentang cara-cara membuat jamu tradicional di masyarakat.

4. Perlunya resep-resep yang sudah direkomendasi kebenarannya oleh pakar, ditulis dalam buku agar dapat diwariskan kepada anak-cucu.

\section{DAFTAR PUSTAKA}

Adhi Wibowo, 2002, Resep Praktis Herbal, Yogyakarta: Adromedia Publishing 
Baskara, A.W. 2010. Sehat Alami Khasiat Buah. Yogyakarta: Kreasi Wacana

Geertz, Hilderd, 1961, Keluarga Jawa, Jakarta, PT. Grafiti Press

Kantor Menteri Negara Kependudukan/BKKBN, 1999. Sambutan Menteri Negara Kependudukan/Kepala BKKBN pada Acara Pembukaan Seminar "Sosialisasi kebijakan dan program Aksi Serta hasil Studi tentang Peningkatan Kualitas lansia, Jakarta

Siti Partini, 1999, Profil Sosial Budaya lansia Dalam Keluarga dan Komunitas di Propinsi Daerah Istimewa Yogyakarta, Laporan Penelitian, Yogyakarta, IKIP Yogyakarta

Sri Iswanti, dkk, 2001, Studi Perbandingan Pola Hidup Lansia Jepang dengan Pola Hidup Lansia Daerah Istimewa Yogyakarta, Laporan Penelitian, Lembaga Penelitian UNY.

Suharti, 2008, Peran Lansia Dalam Pelestarian Budaya, Laporan Penelitian, Yogyakarta, Lembaga Penelitian UNY

Werner, D, Thuman,C, Maxwell, J. 1995. Where There Is No Doctor (terjemahan). Yogyakarta: Yayasan Essentia Medica 